\title{
PELATIHAN "LINGKUNGAN MEDIA SOSIAL KONTEMPORER: TANTANGAN DAN PELUANGNYA" BAGI PEREMPUAN WIRAUSAHA DI WILAYAH JABODETABEK
}

\section{TRAINING ON CONTEMPORARY SOCIAL MEDIA ENVIRONMENT FOR WOMAN ENTREPRENEURS IN JABODETABEK AREA}

\author{
Ezmieralda Melissa ${ }^{1}$, Muninggar Sri Saraswati ${ }^{2}$, Fajrie Samahita $^{3}$ \\ ${ }^{1}$ Department of Public Relations and Communication, Swiss German University \\ ${ }^{2}$ Department of Public Relations and Communication, Swiss German University \\ ${ }^{3}$ Department of Public Relations and Communication, Swiss German University \\ ezmieralda.melissa@sgu.ac.id,muninggar.saraswati@sgu.ac.id,samahitaf@gmail.com
}

\begin{abstract}
Abstrak
Salah satu kaum yang berpotensi untuk mendukung kewiraswastaan, tetapi sering terlupakan, adalah perempuan. Walaupun kaum perempuan mencakup kurang lebih enam puluh persen dari seluruh jumlah pengusaha di Indonesia (Kementrian UMKM, 2009), mereka lebih sering mendapatkan tantangan dalam menjalankan usaha mereka, dibandingkan dengan lelaki pengusaha. Beberapa tantangan yang umum mereka hadapi meliputi akses yang terbatas terhadap permodalan, peran mereka yang beragam baik di keluarga maupun masyarakat, pengetahuan yang terbatas mengenai teknologi informasi dan komunikasi (TIK), dan sistem pendukung yang kurang.

Banyak perempuan yang mengandalkan media sosial untuk memungkinkan mereka menjalankan usaha dari rumah. Walaupun pada umumnya media sosial membawa manfaat positif bagi perempuan pengusaha, dinamika media sosial juga membawa tantangan sendiri bagi kaum ini untuk terus mengikuti perubahan teknologi dan beradaptasi dengan jenis interaksi yang berbeda antara penjual dan pembeli.

Kegiatan Pengabdian kepada Masyarakat (PKM) ini bertujuan untuk memberikan pelatihan capacity building, khusus untuk perempuan yang memiliki usaha mikro, kecil, dan menengah (UMKM) yang dijalankan dalam jaringan (online). Melalui PKM ini, kami memperkenalkan para peserta kepada tantangan-tantangan baru yang dibawa oleh perubahan pada lingkungan media sosial sekarang ini. Selain itu, kami juga mendampingi mereka dalam pembuatan rencana komunikasi media sosial yang efektif, yang dapat membantu mereka mengatasi tantangan-tantangan tersebut di atas. Pelatihan ini juga memberikan kesempatan kepada para peserta untuk membangun jaringan dengan perempuan pengusaha lainnya, yang berpotensi meningkatkan modal sosial mereka.
\end{abstract}

Keywords: kewirausahaan perempuan, media sosial, tantangan, bisnis online, modal sosial.

\begin{abstract}
One group that has the potential to boost entrepreneurship, but is often undervalued is women. Although they consist of approximately sixty per cent of all entrepreneurs in Indonesia, they often face more challenges in comparison to male entrepreneurs in conducting their business ventures. These challenges include limited access to funding, multiple roles and responsibilities in the family and society, limited knowledge of information and communication technologies, and inadequate support system.
\end{abstract}


Many women turn to social media to enable them opening a business that they can manage from home. While generally social media bring positive consequences to these woman entrepreneurs, the dynamic of the social media environment means that these women have to face obstacles to keep up with the technological developments and the changes of interactions that they bring to the business conducts and sellers-consumer interactions.

This community service program aimed to provide capacity building training which focuses on women who own online micro businesses. Through this community service program, we introduced participants to the potential challenges that are brought by the changes in the social media environment. At the same time, we also assisted them in planning an effective social media communication plan that can help them to overcome these challenges. This workshop also allowed participants to network with other woman entrepreneurs that can potentially increase their social capital.

Keywords: woman entrepreneurship, social media, challenges, online business, social capital.

\section{PENDAHULUAN}

Hampir dua puluh lima persen dari jumlah total pemilik Usaha Mikro, Kecil, dan Menengah (UMKM) di Indonesia adalah perempuan (Kementrian Operasi dan Usaha Kecil Menengah dalam Fajar, 2019). Walaupun begitu, perempuan pengusaha lebih cenderung menghadapi tantangan dibandingkan dengan lelaki pengusaha dalam memulai, membangun, dan mempertahankan usahanya. Pertama, banyak perempuan pengusaha yang melaporkan bahwa mereka terkadang tidak dapat mengakses layananlayanan usaha yang diberikan kepada lelaki pengusaha, seperti akses ke bantuan finansial, pelatihan, pendampingan (mentorship), dan lain sebagainya (Gupta \& Aggarwal, 2015). Penelitian yang kami lakukan pada tahun 2011 hingga 2013 juga menemukan bahwa banyak perempuan pengusaha yang menghadapi kesulitan dalam mengajukan permohonan untuk program kredit mikro atau bantuan modal lainnya bagi usaha mereka. Hal ini dikarenakan kedua proses tersebut biasanya memerlukan persetujuan dari suami atau anggota keluarga lain yang berjenis kelamin lelaki dan dapat menjadi penjamin bagi mereka (Melissa, Hamidati, \& Saraswati, 2013). Pada saat yang sama, perempuan pengusaha juga menghadapi tantangan lain dalam mengelola usaha mereka dikarenakan oleh tanggung jawab domestik yang harus mereka emban. Karena budaya di Indonesia cenderung menempatkan perempuan sebagai pengasuh utama anak-anak mereka (Utomo
2018), perempuan memiliki waktu yang lebih terbatas untuk mengelola usaha mereka dibandingkan dengan lelaki pengusaha. Tidak seperti kebanyakan lelaki pengusaha yang dapat mendedikasikan sebagian besar waktunya untuk mengembangkan usaha mereka, perempuan pengusaha biasanya menjalankan wirausaha mereka di sela-sela tanggung jawab domestik mereka, yang sudah sangat banyak.

Perkembangan teknologi informasi dan komunikasi (TIK), khususnya Internet dan media sosial, membawa peluang baru bagi perempuan wirausaha dan perempuan yang ingin menjadi wirausaha. Karena mobilitas dan kemudahan yang ditawarkannya, Internet dan media sosial memungkinkan perempuan untuk memulai usaha mereka sendiri di rumah, menjalankannya dengan biaya minimum, dan di saat yang bersamaan juga menjalankan kewajiban domestik dan sosial mereka (Schaper et al., 2010). Meskipun demikian, lingkungan media sosial sangatlah dinamis. Setiap platform media sosial terus memperkenalkan cara berinteraksi dan berkomunikasi yang baru. Pada saat yang sama, persaingan dalam dunia perdagangan online di Indonesia sangatlah kompetitif. Oleh karena itu, tantangan-tantangan ini perlu dihadapi jika para perempuan pengusaha yang menjalankan usahanya melalui media sosial ingin unggul dalam bisnis online mereka. 


\section{METODE}

Berdasarkan pemahaman ini, program PKM kami dilakukan dalam bentuk pelatihan pengembangan kapasitas (capacity building) untuk perempuan yang memiliki UMKM yang dilakukan dalam jaringan (online). Pelatihan ini bertujuan untuk membantu perempuan wirausaha untuk mengenali peluang dan mengatasi tantangan yang ada pada media sosial dan untuk mempersiapkan mereka dengan lebih baik dalam menjawab tantangantantangan tersebut.

Di bawah ini adalah rincian dari program PKM yang telah kami lakukan:

Lokasi : Hotel Harris FX Sudirman

Tanggal: 24 Juni 2019

Waktu : $8.00-13.00$

Kami memilih untuk melaksanakan pelatihan di daerah Sudirman karena lokasi ini berada di pusat kota Jakarta. Harapan kami adalah pilihan ini memungkinkan para peserta yang berasal dari berbagai daerah di kawasan Jabodetabek untuk menggapai lokasi pelatihan dengan mudah. Hal ini juga didukung oleh banyaknya pilihan moda transportasi untuk menuju lokasi pelatihan.

Pada pelaksanaannya, pelatihan ini dihadiri oleh enam orang perempuan wirausaha yang memiliki atau pernah memiliki UMKM berbasis media sosial. Kami telah mengenal dan menjaga kontak dengan para perempuan ini sejak tahun 2011, saat kami mengadakan penelitian mengenai peran media sosial dalam pemberdayaan perempuan. Kami menjaga hubungan dengan mereka melalui kelompok yang dibentuk di Facebook dimana para perempuan ini, bersama dengan para perempuan wirausaha dari berbagai kota lain di Indonesia, dapat mengakses informasi mengenai usaha berbasis media sosial, program pemberdayaan perempuan, tawaran pembiayaan, dan lain sebagainya.

Profil usaha dari para peserta adalah sebagai berikut: 1) Ratih memiliki usaha online menjual baju renang untuk perempuan Muslim, 2) Lisa dulu pernah memiliki usaha katering kecil yang spesialiasinya adalah tumpeng mini. Lisa juga memiliki blog yang cukup terkenal, Alley's Kitchen, yang isinya adalah cerita perjalanan usaha kulinernya atau resep-resep yang ia uji cobakan, 3) Swistya memiliki toko online yang menjual pakaian
Muslim bagi perempuan maupun anak-anak. Pakaian-pakaian ini merupakan hasil rancangan dan produksinya sendiri, 4) Iin memiliki toko online yang menjual hijab-hijab mewah, 5) Nien memiliki toko online shop yang menjual pasta buatan rumah sendiri, 6) Dwita adalah seorang perempuan yang memiliki keinginan untuk merintis usaha online untuk menjual produk-produk untuk bayi. Jumlah peserta pada program PKM kali ini jauh lebih sedikit dari target yang kami tetapkan. Evaluasi akan keberhasilan program ini akan kami paparkan secara lebih lengkap pada bagian berikutnya, yaitu hasil dan pembahasan.

Dalam pelaksanaannya, program PKM ini dibagi menjadi dua, yaitu diskusi kelompok terpumpun (DKT) dan pelatihan. Program dimulai dengan diskusi kelompok terpumpun yang bertujuan untuk mengumpulkan informasi tentang tantangan yang dihadapi oleh para peserta kami dalam menjalankan usahanya, yang dibawa oleh perkembangan media sosial kontemporer. Di bagian kedua dari program ini kami menyediakan pelatihan untuk para peserta. Pelatihan ini juga dibagi menjadi dua sesi. Sesi pertama adalah presentasi tentang perubahan lingkungan media sosial dan peluang yang dibawanya bagi UMKM. Sesi ini dilanjutkan dengan kerja kelompok di mana para peserta, di bawah bimbingan kami, membahas dan mengembangkan rencana untuk mengatasi tantangan-tantangan ini dan mengadaptasi strategi media sosial baru untuk usaha mereka.

\section{HASIL DAN PEMBAHASAN}

Ada beberapa kriteria, baik kuantitatif maupun kualitatif, yang kami terapkan untuk mengukur keberhasilan program PKM ini, yaitu: 1) setidaknya ada dua belas peserta yang berpartisipasi dalam pelatihan ini, 2) setidaknya sembilan puluh persen dari peserta menyatakan bahwa mereka puas dengan isi dari pelatihan ini, 3) peserta mendapat kesempatan untuk memperluas jaringan dan menambah modal sosial mereka melalui pertemuan dengan perempuan pengusaha lainnya, dan 4) lokakarya menghasilkan ideide baru untuk kegiatan pengembangan 
kapasitas di masa depan, yang terfokus pada perempuan wirausaha.

Berdasarkan kriteria keberhasilan yang kami sebutkan di atas, berikut ini adalah evaluasi dari pelaksanaan program UMKM kami: 1) Hanya enam orang peserta yang dapat hadir ke program PKM kami dari target dua belas orang peserta. Kami tidak dapat mencapai tujuan untuk mendapatkan dua belas orang peserta dikarenakan seluruh peserta kami adalah perempuan wirausaha yang bekerja sendiri sehingga mereka merasa sulit untuk mengalokasikan waktu untuk menghadiri acara tersebut. Di saat yang bersamaan, para peserta juga merasa kesulitan untuk hadir pada program PKM kami dikarenakan sebagian besar dari mereka masih memiliki anak kecil yang harus mereka urus. Walaupun kami memperbolehkan para peserta untuk membawa anak-anak mereka ke pelatihan, banyak calon peserta yang masih merasa bahwa hal tersebut akan mengganggu mereka dalam mengikuti pelatihan ini. 2) seluruh peserta menyatakan bahwa mereka puas dengan pelatihan ini. Mereka percaya bahwa pelatihan ini dapat membantu mereka mengembangkan rencana komunikasi media sosial yang solid untuk usaha mereka. Salah satu peserta pelatihan, Iin, mengatakan "Alhamdulillah, ada begitu banyak hal baik yang saya pelajari hari ini. Insya Allah bisnis saya akan terus tumbuh. ", 3) Seluruh peserta merasa bahwa pelatihan ini membantu memperluas jaringan dan modal sosial mereka. Semua peserta merasa bahwa diskusi kelompok terpumpun yang kami lakukan di awal program telah membantu mereka untuk belajar dari pengalaman satu sama lain dan memberi mereka ide-ide baru untuk mempertahankan dan mengembangkan usaha mereka. Seluruh peserta juga saling bertukar nomor telepon dan berjanji untuk mengatur pertemuan untuk membahas ide-ide yang dapat memperluas usaha mereka, 4) pelatihan ini telah mampu menghasilkan ide-ide baru untuk kegiatan pengembangan kapasitas di masa depan yang berfokus pada perempuan wirausaha. Ratih, salah satu peserta yang telah mengelola inkubator usaha untuk membimbing beberapa wirausahawan baru, menyatakan kesediaannya untuk terlibat dalam program
PKM yang kami adakan di masa depan, yang berfokus pada perempuan wirausaha.

Berkaca dari pencapaian kriteria keberhasilan yang kami uraikan di atas, dapat dikatakan bahwa program PKM kami cukup sukses. Walaupun kami tidak dapat memenuhi kriteria jumlah peserta, tetapi ketiga kriteria keberhasilan kami lainnya telah tercapai, bahkan melebihi apa yang kami harapkan. Selain itu, salah satu hal terpenting dalam pemberdayaan perempuan wirausaha adalah terbangunnya modal sosial.

Taylor et al. (2004) mendefinisikan modal sosial sebagai nilai produktif yang diperoleh individu dan kelompok karena hubungan jaringan sosial di antara mereka. Modal sosial sendiri berpengaruh besar terhadap akses para individu tersebut ke berbagai sumber daya lain. Modal sosial sendiri dapat dibagi menjadi tiga jenis yaitu struktural, relasional dan kognitif (Nahapiet dan Ghoshal, 1998). Modal sosial struktural mengacu pada jumlah jaringan yang terjadi dikarenakan hubungan antar individu, relasional mengacu pada kualitas hubungan yang terjalin antar individu dan dampak yang dihasilkannya, dan kognitif meliputi jenis pemahaman yang berkembang antar individu tersebut (Nahapiet dan Ghoshal, 1998).

Walaupun kami belum mengukur secara terperinci pengaruh ketiga jenis modal sosial tersebut terhadap masing-masing peserta, namun kami mengetahui bahwa beberapa peserta pelatihan telah bertemu di kesempatan lain untuk membahas usaha mereka dan rencana kolaborasi untuk mengembangkannya. Agar efek positif ini dapat terus terjadi dan semakin meluas, kami berpikir untuk memfasilitasi kegiatan-kegiatan pendukung di masa mendatang, yang fokusnya khusus untuk mengembangkan modal sosial para peserta. Selain itu, untuk memastikan bahwa kami dapat mencapai target jumlah peserta di pelatihan-pelatihan yang akan datang, kami harus bekerja sama dengan kelompok perempuan wirausaha setempat. Pelatihan dapat digabungkan dengan pertemuan rutin kelompok tersebut sehingga dapat dipastikan peserta yang datang akan cukup banyak.

Selain manfaat yang didapat oleh para peserta, kami sebagai pelaksana pelatihan 
pun juga belajar banyak dari program PKM ini. Kami belajar bagaimana para perempuan wirausaha mencari celah untuk mengembangkan bisnis mereka di lingkungan yang sangat kompetitif ini. Selain itu kami juga belajar bahwa para perempuan ini sangat bersemangat untuk menularkan keberhasilan usahanya kepada para perempuan lain. Beberapa peserta kami yang baru memulai bisnis mereka pada tahun 2011 (kontak pertama kami dengan mereka) bahkan telah berkembang menjadi inkubator dan mentor bagi perempuan wirausaha lain. Hal ini sesuai dengan teori modal sosial yang mengatakan bahwa nilai-nilai produktif tambahan dapat muncul sebagai hasil dari hubungan yang terjalin antara sesama anggota jaringan sosial (Taylor et al., 2004). Semangat ini adalah hal yang sangat inspiratif yang memacu kami untuk menjamin keberlanjutan program PKM seperti ini di masa mendatang.

\section{KESIMPULAN}

Kewirausahaan perempuan semakin penting bagi perkembangan ekonomi masyarakat. Bukan saja secara jumlah, para perempuan wirausaha juga memiliki potensi tinggi untuk menularkan virus kewirausahaannya kepada para perempuan lain atau calon pengusaha lainnya.

Namun sayangnya perempuan masih banyak menghadapi halangan dalam memulai, mengembangkan, dan mempertahankan usahanya. Halangan ini dapat berupa halangan struktural seperti sulitnya mendapatkan permodalan tanpa persetujuan anggota keluarga yang berjenis kelamin lelaki, maupun halangan sosio-kultural seperti tuntutan budaya yang mengharuskan perempuan untuk mengambil peran yang lebih dominan dalam menjaga anak-anak dan pekerjaan rumah tangga lainnya.

Kegiatan PKM seperti yang kami adakan ini memberikan berbagai manfaat positif bagi para perempuan wirausaha maupun perempuan lain yang ingin menjadi pengusaha. Bukan saja pelatihan seperti ini dapat membantu mereka untuk membangun perencanaan yang solid untuk menjawab tantangan-tantangan yang terjadi karena perubahan teknologi informasi dan komunikasi yang cepat. Namun kegiatan ini juga memberikan kesempatan bagi para peserta untuk bertemu dengan para perempuan wirausaha lainnya. Pertemuan ini berpotensi menjadi awal untuk kegiatan kolaborasi maupun pertemuan-pertemuan lain di masa mendatang. Kedua manfaat tersebut berpotensi besar untuk meningkatkan modal sosial para perempuan pengusaha. Modal yang dianggap sebagai sala satu hal terpenting dalam keberlangsungan sebuah kegiatan kewirausahaan, apalagi yang dijalankan oleh perempuan.

\section{UCAPAN TERIMA KASIH}

Program PKM ini terlaksana atas dukungan dana dari skema pembiayaan PKM Central Community Service Fund dari Universitas Swiss German.

\section{REFERENSI}

Fajar, T. (2019, March 6). '14 juta usaha di Indonesia dikelola wanita'. Oke Finance. Retrieved from: https://economy.okezone.com/read/2019 /03/06/320/2026418/14-juta-usaha-diindonesia-dikelola-wanita.

Gupta, S. and Aggarwal, A. (2011). 'Opportunities and challenges faced by women entrepreneurs in India'. IOSR Journal of Business and Management, 17(8), pp. 69-73.

Melissa, E., Hamidati, A., and Saraswati, M. S. (2013) 'Social media empowerment: how social media help to boost women entrepreneurship in Indonesian urban areas'. The Iafor Journal of Media, Communication \& Film, 1(1), pp.77-90.

Nahapiet, J. and Ghosal, N. (1998). 'Social capital, intellectual capital, and the organizational advantage'. The Academy of Management Review, 23(2), pp. 242-266.

Schaper, M., Volery, T., Weber, P., and Lewis, K. (2010). Entrepreneurship and Small Businesses. Milton, Queensland: John Willey and Sons. 
Taylor, D. W., Jones, O., Boles, K. (2004). 'Building social capital through action learning: an insight into the entrepreneur'. Education + Training, 46(5), pp. 226-235.
Utomo, A. (2018). 'Meninjau kembali tren partisipasi angkatan kerja perempuan di Indonesia'. Jurnal Perempuan, 23(4), pp. 193-202. 